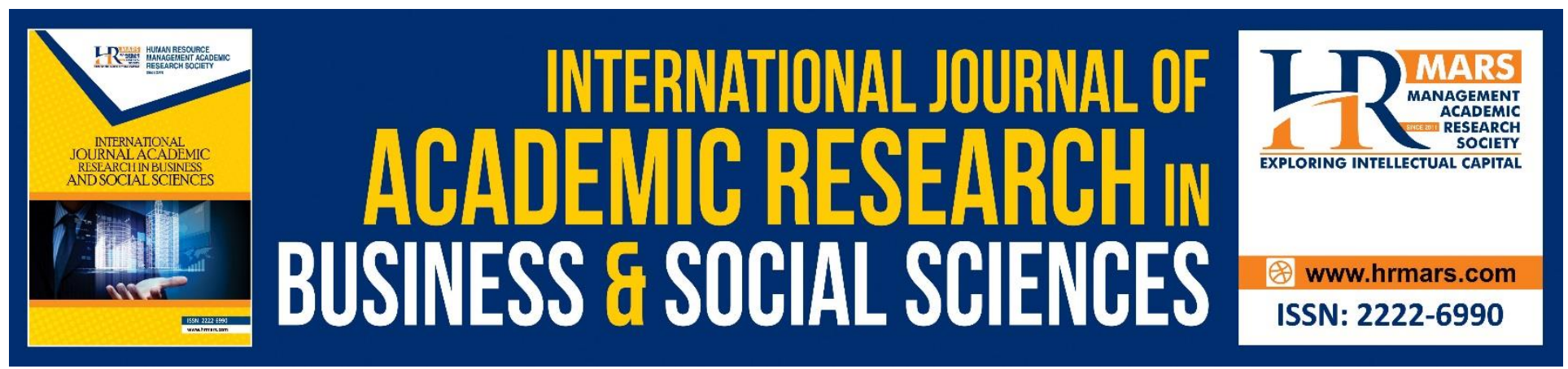

\title{
Selection of Successors to Family Businesses in Taiwan: Case Study on Small and Medium Enterprises
}

Tzong-Ru Lee, Yong-Shun Lin, Ching-Yi Wang

To Link this Article: http://dx.doi.org/10.6007/IJARBSS/v10-i7/7473

DOI:10.6007/IJARBSS/v10-i7/7473

Received: 02 April 2020, Revised: 06 May 2020, Accepted: 21 June 2020

Published Online: 26 July 2020

In-Text Citation: (Lee, Lin, Wang, 2020)

To Cite this Article: Lee, T-R., Lin, Y-S., Wang, C-Y. (2020). Selection of Successors to Family Businesses in Taiwan: Case Study on Small and Medium Enterprises. International Jornal od academic research in business \& social Sciences, 10(7), 590-606.

\section{Copyright: (C) 2020 The Author(s)}

Published by Human Resource Management Academic Research Society (www.hrmars.com)

This article is published under the Creative Commons Attribution (CC BY 4.0) license. Anyone may reproduce, distribute, translate and create derivative works of this article (for both commercial and non-commercial purposes), subject to full attribution to the original publication and authors. The full terms of this license may be seen at: http://creativecommons.org/licences/by/4.0/legalcode

Vol. 10, No. 7, 2020, Pg. 590 - 606

Full Terms \& Conditions of access and use can be found at http://hrmars.com/index.php/pages/detail/publication-ethics 


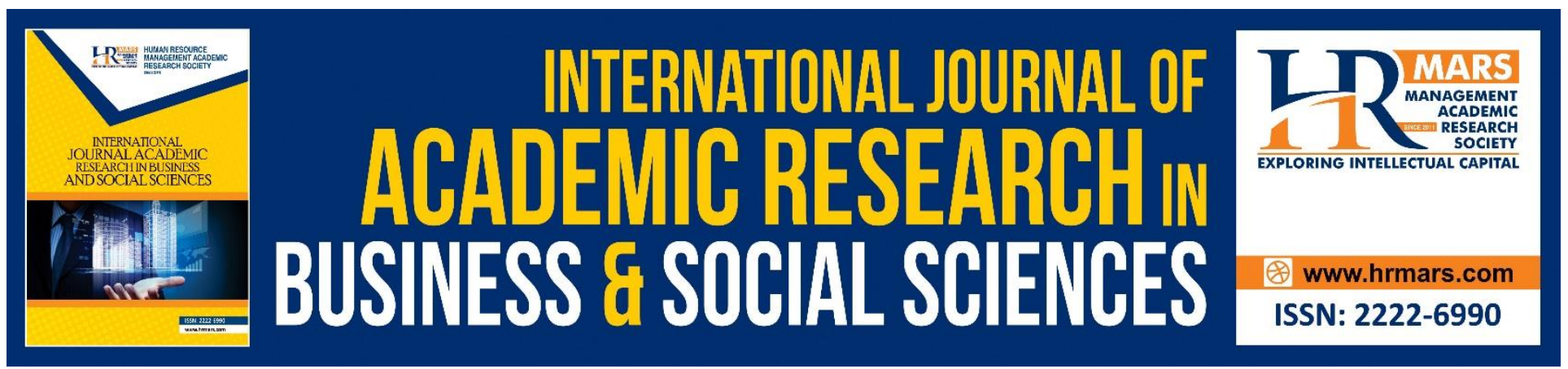

\title{
Selection of Successors to Family Businesses in Taiwan: Case Study on Small and Medium Enterprises
}

\author{
Tzong-Ru Lee ${ }^{\mathrm{a}}$, Yong-Shun Lin ${ }^{\mathrm{b}}$, Ching-Yi Wang ${ }^{\mathrm{c}}$ \\ a Professor, Department of Marketing, National Chung Hsing University, Taiwan R.O.C., b Assistant \\ Professor, Department of International Business, Ling Tung University, Taiwan, R.O.C., ' Doctor, \\ Department of Forestry, National Chung Hsing University. \\ Email: byongshun10@gmail.com
}

\begin{abstract}
The purpose of the study is to explore the methods which small and medium-sized family businesses in Taiwan adopt for selecting successors, the characteristics of successors, and the suitability of children's or professional managers' succession to family businesses. The qualitative interview was adopted to establish the contents of the survey, and 400 questionnaires were distributed to the original owners (bosses) of small and medium-sized family businesses, second generation successors (children), professional managers, graduate students in the EMBA program, and cadre members of trade associations. A total of 349 valid questionnaires were retrieved (87.25\%). The grey relational analysis (GRA) was adopted as the statistical method of the study. According to the results of the study, the most common method for training successors was reserve cadre; the selection of successors was mainly based on the opinions of the bosses or chairmen; personal morality weighed heavily in the characteristics of successors; and professional managers' succession improved the overall business performance.
\end{abstract}

Keyword: Small and Medium Enterprises, Successors, Grey Relational Analysis.

\section{Introduction}

As the size of a family business expands, the family maintains the operation of the family business and the control of the members through cross ownership, mutual directorship, or pyramid structure (Almeida and Wolfenzon, 2006; Claessens, Djankov, and Lang, 2000; La Porta, LopezdeSilanes, and Shleifer, 1999; Levy, 2009). However, the succession of family businesses is crucial, and it will attract the attention of the public (Cabrera-Suarez, De Saa-Perez, \& Garcia-Almeida, 2001). Succession is a sensitive subject, where the conflicts and disintegration of family businesses need to be addressed. To ensure the family business continuity, the key subject that need to be addressed is the succession and structure of the management (Tirdasari \& Dhewanto, 2012), which is a challenging process (Mussolino \& Calabro, 2014). The succession plan plays an important role in the success of a family business. A good succession plan is conducive to the sustainable development of a family business (Ahlers, Hack, \& Kellermanns, 2014; Cater III \& Kidwell, 2014; Brockhaus, 2004; Ward, 1987). 
INTERNATIONAL JOURNAL OF ACADEMIC RESEARCH IN BUSINESS AND SOCIAL SCIENCES Vol. 10, No. 7, July, 2020, E-ISSN: 2222-6990 @ 2020 HRMARS

Lack of thorough succession planning increases the risk of business failure (Barach, Gantisky, Carson, \& Doochin, 1988; Seymour, 1993). Therefore, when selecting successors to the operation of family businesses, family businesses face the risk of whether successors are able to lead the family businesses to advance.

Family businesses have a very important position in the development of the global economic. A family business is characterized by a small number of family members as the major controlling shareholders, and at least two members of the family (once) directly involved in the management of the family business (Kram \& Isabella, 1985). Mark and Tom (2013) indicated that family businesses could take risks flexibly and implement long-term investment strategies. Morck et al. (2005) pointed out that the proportion of family-controlled groups in European companies was about $19 \%$ in Australia, 30\% in Belgium, 22\% in Finland, 29\% in France, $21 \%$ in Germany, $14 \%$ in Ireland, $20 \%$ in Italy, 23\% in Norway, 34\% in Portugal, 11\% in Spain, 13\% in Sweden, 29\% in Switzerland, and 4\% in the U.K.; in addition, American family businesses provided almost $80 \%$ of jobs in the U.S. (Lansberg \& Gersick, 2015). Since the Western countries, such as the U.K. and the U.S., emphasize entrepreneurship, the ownership and management of enterprises are separate. To avoid direct participation in business operations, major shareholders engage professional managers to manage the enterprises for the overall interests of the enterprises. According to Luan, Chen, Huang \& Wang, (2018), when the incumbent CEO is a family member, the family business is more likely to select an internal member as the new CEO; however, when external directors have a large shareholding, the family business tends to select the new CEO from external sources. This shows that family businesses play a very important role in the world, and Western countries prefer engaging professional managers to manage enterprises. The management of family businesses is not always based on the hereditary concept; it is possible to engage professional managers to manage family businesses. The stakeholders of an enterprise have a great influence on the succession decision of the family business, which means that the successful succession of a family business can be difficult (Luan, Chen, Huang \& Wang, 2018).

Family businesses are a common type of management for enterprises in the Chinese-speaking world (Fukuyama, 1995; Weidenbaum \& Hughes, 1996). In Taiwan, familial management is not only the basic organizational structure for the operation of small and medium-sized enterprises, but also one of the important factors affecting the strategy implementation and transformation of conglomerates (Yiu, Bruton, and Lu, 2005). The Economist (2018) has recently published an article titled "Taiwanese Bosses Are the Chinese-speaking World's Oldest". According to the survey of Taiwan Institute of Directors, among all listed companies, 33\% were family businesses in China, $40 \%$ in Hong Kong, and $70 \%$ in Taiwan, and the founders of three-fourths of the family businesses in Taiwan were responsible for daily operations. The average age of CEOs of listed companies in Taiwan was 62 years old, while that in China was only 47 years old.

Family businesses in Taiwan have their particularity and repre-sentativeness, as the promotion of employees in Taiwan businessesis measured mainly according to employee loyalty to the business, and not their performance, which is also an essential difference between Taiwan and other countries, in particular European and American countries, regarding the treatment of human resources (Wang, Lo \& Weng, 2019). The founders of family firms commonly bequeath themanagement of their enterprises to family members (Xu, Yuan, Jiang, \& Chan, 2015; Yeh, 2019). As Taiwanese families have many children and clan relatives, family members have a strong connection, and this blood tie tends to cause the succession willingness of a family successor to be 
ignored. And Taiwan is a country dominated by small and medium-sized enterprises, and small and medium-sized family businesses often face a problem of successor selection. When considering successor candidates, business owners usually give priority to their children and grandchildren, that is, their ability to become successors before being of age. When children in the family have grown up to a certain age, there may be more than one person who has the ability to serve as a successor; business owners select the best from several children who meet the ability to succeed and train $\mathrm{him} / \mathrm{her}$ to become a true successor. After successor candidates are selected, they will be trained to succeed and observed closely. It is possible to find outstanding professional managers outside the family members after observations, and they may be selected to enhance the competitiveness of family businesses. Business owners have to make a choice between professional managers and family members to determine the best successors. Family firm succession is typically a long process rather than an event in which there is a management change (Handler, 1994; Steier \& Miller, 2010). All of the above shows that Taiwan is facing the generation of successors. The purpose of the study is to explore the methods which small and medium-sized family businesses in Taiwan adopt for selecting successors, the characteristics of successors, and the suitability of children's or professional managers' succession to family businesses, so as to understand the criteria for succession planning at different stages and the succession methods.

\section{Literature Review}

\section{What is Succession Planning}

Succession planning is the key to the talent market and competition (Pandey \& Sharma, 2014). Succession planning needs to analyze the views of the family, management and ownership and understand the different interests of each viewpoint accurately (Brockhaus, 2004). The process of succession is dynamic and is a combination of activities relating to inheritance during a specific period of time. The duration of succession varies with the nature and size of individual enterprises. The inheritance mostly starts from the "second generation's contact with business management", and ends at "the owner's release from authority and leadership in decision-making of the enterprise" (Longenecker \& Schoen, 1978).

Succession planning refers to a process where organizations cultivate leaders through systematic definition, assessment, and development and further improve its business performance. In this process, successors must develop the ability to manage business and build their own power (Lansberg, 1988), and select the right employee as the successor (Spurk \& Abele, 2011). Fiedman (1986) indicated that succession planning was based on the succession event and planning procedures, including the implementation of administration and staffing, and gradually focused on the evaluation and development of human resources, selection of new recruits, and appointment of the management. Couch (2013) defined succession planning as a conscious and systematic effort to accelerate the development of candidates' mission-critical leadership through a programmatic approach, with regular measurement of progress.

Intergenerational succession is defined as the intent to pass family businesses to future generations (Churchill \& Hatten, 1987; Hauck et al, 2016); however, the successor may not be a member of the original family (Sharma, 2004; Steier \& Miller, 2010). Kansikas \& Kuhmozen (2008) pointed out that succession was a necessary and crucial economic evolution process for most family businesses. It could bring different cultural stimuli to enterprises, but it might also become a source of organizational conflicts making changes in the internal quality of organizations. Succession helps 
introduce new resources to curb the risks caused by centralized management (Bamford, Bruton \& Hinson, 2006); however, it may also cause conflicts or struggles and become obstacles to the sustainable development of family businesses (Eddleston \& Kellermanns, 2007). This shows that succession is the problem that family businesses encounter. In the process of organizational evolution, succession may bring new weather and also cause obstacles, such as family conflicts. Enterprises know the importance of succession planning, but few leaders have actual succession planning (Calareso, 2013).

In the implementation of succession planning, enterprises often organize activities to train successors for leadership, organizational thinking, high-level management, and business strategies. Longenecker and Schoen (1978) believed that succession was the process of socialization for successors, where successors had to constantly play different roles and positions to gain the knowledge, skills and positions required to succeed. By participating in these activities, successors could learn and apply relevant skills more effectively, and apply what they had learned to manage their business operations in the future. Common succession planning activities include EMBA (Executive Master of Business Administration) programs, expatriates, workshop, job rotation, mentoring, job-shadowing, job assignments, coaching, and action learning (2007; Groves, 2007; Waruiru \& Kagiri, 2013).

According to Salvato et al (2015), training for the main members of family businesses was divided into four stages: 1 . Pre-university; 2. University, 3. Graduate institute, and 4. Advanced training. In the pre-university stage, family members absorbed the value, attitudes and experience of family businesses, allowing younger generations to participate in simple work and contact the community and learn from older family owners about the basics of business. In the university stage, young family members participated in corporate work in addition to attending business courses at the university. In the graduate institute stage, young family members absorbed professional business knowledge and learned how to solve the insufficient knowledge of family businesses and the relationship between family members. In the advanced training stage, young family members learned leadership skills in addition to high-level expertise. Sorenson and Milbrandt (2015) proposed three training levels for family businesses: 1 . Training was placed in the center of family businesses, allowing the next-generation successors to discuss business management related issues and gradually enter the core of family businesses; 2 . New training contents and resources were developed, such as attending graduate courses during the undergraduate program, learning more business knowledge through optimized courses, or meeting more professional managers; 3 . Training was bilateral, where new generations conceived new ideas and received guidance from the incumbent management to facilitate the successful succession to family businesses.

All of the above shows that small and medium-sized family businesses have various ways to select successors, including reserve cadre, job rotation, expatriates, mentoring, and EMBA program. In general, since childhood, members of family businesses have received planned training for professional knowledge of family businesses and, more importantly, leadership, and even received training in other enterprises.

\section{Characteristics Required for Successors to Family Businesses}

Family businesses have a great influence on the economy of the Chinese-speaking world. Therefore, the inheritance and management of family businesses affect the rise and fall of enterprises. At present, enterprises in the Chinese-speaking world are generally facing the problems 
of transformation and succession. To successfully manage family businesses and sustain long-term business growth, it is necessary to accurately implement the selection and training of successors. As a successor is the person with actual power, his/her personal traits and leadership will inevitably affect the strategies and operations of family businesses. An excellent successor must have all-round qualities. Following the previous generation, successors are responsible to lead and coordinate corporate decisions and drive the growth of the companies to enhance the strengths and competitiveness of the companies. According to related studies, successors should have the following capabilities: innovation, deliberation, insight, leadership, expressiveness, initiative, agility and sustainability, creativity and acumen, softness and growth, ambition, diversity and professionalism, influence, determination, risk-taking and forward-looking attitude, nurture and communication, modesty and self-confidence, responsibility, high resistance and frustration resilience (Hamilton et al., 2017; Maloni et al, 2017; Hsu et al, 2016; Cana-Rubio, Fuentes-Lombardo \& Vallejo-Martos, 2017). To simplify the above characteristics, the study classified them into three categories: morality, leadership, and work performance.

\section{Criteria for Selecting Successors to Family Businesses}

A common trend in organizational development is the inconsistency between succession planning for leaders and the criteria for evaluating the effectiveness of succession planning for work performance (Greer \& Virick, 2008). In succession planning, it is important to find someone who can lead a company (Garman \& Tyler, 2004) with role-playing ability, communication skills, participation in social activities, interaction with family members, morality and professionalism, relevant experience, language proficiency (internationalization), connections, management skills, industry expertise, persuasiveness, exhibition, attitude and value (Breton-Miller \& Miller, 2014; Cana-Rubio, et al, 2017; Goel \& Roessl, 2015; Hamilton et al., 2017; Hsu et al, 2016; Konopaski \& Jack, 2015; Maloni et al, 2017; Sorenson \& Milbrandt, 2015); in addition, Due to internal or external training in family businesses, the learning process of potential successors is different. When family members should return to their own businesses depends on many factors, and there is no standard answer.

2.4 Criteria for selecting family members or professional managers as successors to family businesses

For family businesses, the agency issue exists between family shareholders who make decisions and minor shareholders who can only accept decisions made (Morck \& Yeung, 2003; Morck et al., 2005; Young et al., 2008). The results of related studies indicated that larger organizations tended to adopt internal successors rather than external successors (Boeker \& Goodstein, 1993). Selecting external successors had a positive effect on organizational change (Miller, 1993); however, some studies found that selecting external successors might increase the turnover of the management and had a negative impact on organizational morale (Friedman \& Saul, 1991). The shareholding structure would also affect the choice of successors. When employees and professional managers own most of a company's equity, the possibility of selecting external successors will be low (Boeker \& Goodstein, 1993; Dalton \& Kesner, 1983). Most enterprises hoped that family members would succeed, and the shareholding of family businesses had a positive relationship with the company's performance (Anderson \& Reeb, 2003). Some studies also pointed out that professional managers could effectively regulate the possible disadvantages of family business holdings and further improve the company's performance (Anderson \& Reeb, 2004).

If the CEO of a family business is inherited by the eldest son, it will have a bad impact on performance. However, if the CEO is elected by the family, the performance of the company will not 
be worse than that of a general company (Bloom \& van Reenen, 2007). Some studies also pointed out that the performance of a family business where the CEO was an in-law or blood relative would be worse (Pe'rez-Gonza'lez, 2006). According to Farrington et al. (2014), non-family members were very concerned about the content of the work in the family business and whether communication between family members was smooth; however, family businesses paid attention to the past work experience of non-family members. Scholes and Wilson (2014) pointed out that, in the U.K., family businesses would protect the interests of families and businesses through the establishment of trust funds; in addition, family businesses in the U.K. relied on the trust fund system to sustain the growth of knowledge of business management, which was also the factor influencing the survival of family businesses (Scholes \& Wilson, 2014); that is, professional managers were engaged to protect the financial integrity and the continuity of the family businesses through the trust system. There are many studies in which enterprises selected family members or professional managers as successors. The selection of professional managers was helpful to the organization's transformation, but it could result in the turnover of the management. If a family member succeeds, the business performance depends on the management of the successor. Selecting family members or professional managers as successors has its advantages and disadvantages. According to related studies, in the selection of family members or professional managers as successors, family businesses should consider factors, such as communication with family members, past work experience, hiring professional managers as trust managers, influence of the family business system on the company's finances (Farrington et al, 2014; Hamilton et al., 2017; Maloni et al, 2017; Scholes \& Wilson, 2014).

\section{Research Methods}

\section{Subject of Study}

Based on the literature, the study designed a qualitative in-depth interview for 10 members of family businesses studying in the EMBA program to explore the capabilities required for second generation successors and the criteria for selecting successors to family businesses. The results of the interview showed that most of the members agreed that the capabilities required for second generation successors included relevant experience, language proficiency (internationalization), responsibility, high resistance and frustration resilience, ambition, and innovation. Based on the results of the interview and literature review, the capabilities required for successors increase from 3 categories to 6 categories, namely morality, leadership, work performance, capabilities other than expertise, seniority, and external conditions.

To explore the factors in selecting successors to family businesses in Taiwan, the study targeted the original owners (bosses) of small and medium-sized family businesses, second generation successors (children), professional managers, graduate students in the EMBA program, and cadre members of trade associations.

\section{Content of Survey}

Based on the results of the qualitative interview, the study designed the quantitative survey, which was divided into four parts, namely personal information, succession methods for small and medium-sized family businesses, characteristics of successors, and comparison between successors to small and medium-sized family businesses and professional managers. For the validity of the survey, the study interviewed experts and scholars from different countries, including Spain, the U.K., Sweden, and Finland, to understand local succession planning. 
INTERNATIONAL JOURNAL OF ACADEMIC RESEARCH IN BUSINESS AND SOCIAL SCIENCES Vol. 10, No. 7, July, 2020, E-ISSN: 2222-6990 @ 2020 HRMARS

\section{Statistical Method}

The study adopted the grey rational analysis (GRA). GRA can make up for the traditional mathematical statistics that require a large number of data, relevance and normal between variables, and low impact factors, and can deal with uncertainties, multivariate input, discrete data, and incomplete data. GRA can be used as a method to judge the degree of correlation between discrete sequences and quantify the degree of correlation between factors mainly based on the degree of geometric similarity between the reference series and the comparison series. The greater the correlation between the calculated comparison series and the reference series, the more relevant the comparison series to the reference sequence. According to Julong Deng (2005), GRA could be divided into three steps: calculating grey relational coefficient, calculating grey relational grade, and forming grey relational sequence. The formulas are as follows:

(1) Calculating grey relational coefficient: Comparison between points.

$$
\gamma\left(x_{0}(\mathrm{k}), x_{i}(\mathrm{k})\right)=\frac{x(\min )+\zeta x(\max )}{\Delta_{0}(k)+\zeta x(\max )}
$$

(2) Calculating grey relational grade: Comparison between sequences (average the grey relational coefficients calculated from all data).

$$
\gamma\left(x_{0}, x_{i}\right)=\frac{1}{n} \sum_{k=1}^{n} \gamma\left(x_{0}(k), x_{i}(k)\right)
$$

(3) Forming grey relational sequence: Sorting of calculated grey relational grades in order (from large to small). The higher the ranking, the greater the grey relational grade and importance. When the grey relational coefficient is closer to 1 , the reference sequence is more correlated with the comparison sequence; when it is closer to 0 , the correlation between the two is lower.

The grey relational coefficient can express the degree of correlation of each factor between the comparison sequence and the reference sequence. To facilitate comparison, information on the grey relational coefficient is concentrated at one point. Assuming that the weights of the factors between the comparison sequence and the reference sequence are the same, the grey relational grade is as shown in Equation (2), which is the average of the grey relational coefficient. This also represents the degree of correlation between the comparison sequence and the reference sequence. If the two sequences change consistently, the degree of correlation is higher; otherwise, it is lower (Deng, 1997). The numerical values representing the degree of correlation between the two sequences are sorted in order to form the grey relational sequence, which can be used as the key basis for analysis and decision-making.

In addition, another characteristic of GRA is that the degree of correlation between factors can be measured by the degree of similarity or dissimilarity between factors. The study adopted GRA to extract the key factors in succession provided by the respondents, which could serve as the basis for developing future successors to family businesses.

\section{Results of Study}

400 questionnaires were distributed to the original owners (bosses) of small and medium-sized family businesses, second generation successors (children), professional managers, graduate students in the EMBA program, and cadre members of trade associations. A total of 349 valid questionnaires were retrieved (87.25\%). The quantitative survey was divided into four parts, namely personal information, succession methods for small and medium-sized family businesses, 
INTERNATIONAL JOURNAL OF ACADEMIC RESEARCH IN BUSINESS AND SOCIAL SCIENCES Vol. 10, No. 7, July, 2020, E-ISSN: 2222-6990 @ 2020 HRMARS

characteristics of successors, and comparison between successors to small and medium-sized family businesses and professional managers.

According to the results of the study, the ratio of male respondents to female respondents was average, with male respondents and female respondents accounting for $58.0 \%$ and $42.0 \%$, respectively. In terms of age, most of the respondents were between 31 and 55, falling into the young and middle-aged population. As to education, most of the respondents held a bachelor's degree or above and were highly educated; in addition, most of the respondents worked in Northern and Central Taiwan for companies having operated for more than 21 years. The industry types of the companies were mainly service, followed by information and technology. In terms of seniority, most of the respondents had 5 10 years of seniority. Most of the respondents were professional managers, while $62.5 \%$ of the companies did not have overseas branches.

Based on the literature review, common training methods for successors to small and mediumsized family businesses included the following: 1. Reserve cadre; 2. Job rotation; 3. Expatriates; 4. EMBA program; 5. Mentoring. The respondents were asked to select commonly used and less commonly used training methods based on the training methods used by their companies.

According to the results of the analysis, the most commonly used training method was reserve cadre, while the least commonly used training method was to participate in the EMBA program; in addition, the respondents believed that the most effective training method was job rotation, while the most ineffective training method was to participate in the EMBA program. In terms of duration of training, the respondents believed that the most time-consuming training method was reserve cadre, while the least time-consuming training method was to participate in the EMBA program. The details are shown in Table 1 below.

Chung and Luo (2013) discussed the development method of the second generation successor of business, as based on small and medium-sized family businesses in Taiwan, succes-sors that have grown up in the environment of the family business can easily build the recognition and sense of belonging required for holding a position in a family business in the future. They encourage their children to participate in family business and send them to management or business school (Tirdasari \& Dhewanto, 2012). Therefore, the research of reserve cadre is most often used and its results are the best.

Table 1 Frequency of Training Methods for Successors to Family Businesses

\begin{tabular}{llllll}
\hline Training Method & $\begin{array}{l}\text { Reserve } \\
\text { Cadre }\end{array}$ & $\begin{array}{l}\text { Job } \\
\text { Rotation }\end{array}$ & Expatriates & Mentoring & $\begin{array}{l}\text { EMBA } \\
\text { Program }\end{array}$ \\
\hline Commonly Used & 222 & 209 & 148 & 119 & 66 \\
\hline Ranking & $\mathbf{1}$ & $\mathbf{2}$ & $\mathbf{3}$ & $\mathbf{4}$ & $\mathbf{5}$ \\
\hline Effective & 240 & 255 & 175 & 141 & 80 \\
\hline Ranking & $\mathbf{2}$ & $\mathbf{1}$ & $\mathbf{3}$ & $\mathbf{4}$ & $\mathbf{5}$ \\
\hline Time-consuming & 186 & 162 & 120 & 156 & 104 \\
\hline Ranking & $\mathbf{1}$ & $\mathbf{2}$ & $\mathbf{4}$ & $\mathbf{3}$ & $\mathbf{5}$ \\
\hline
\end{tabular}

Source: The study.

The study adopted GRA to analyze the following six characteristics of successors to small and medium-sized family businesses: 1 . Morality; 2. Leadership; 3. Work performance; 4. Capabilities other than expertise; 5 . Seniority; 6 . External conditions. The calculated grey relational coefficients 
INTERNATIONAL JOURNAL OF ACADEMIC RESEARCH IN BUSINESS AND SOCIAL SCIENCES Vol. 10, No. 7, July, 2020, E-ISSN: 2222-6990 @ 2020 HRMARS

were sorted in order to explore the key characteristics of successors provided by the respondents. The results of the analysis, as shown in Table 2, showed that small and medium-sized family businesses valued morality most (0.90), followed by leadership (0.86) and work performance (0.76).

Schlepphorst and Moog (2014) research found evidence of a systematic order of and importance assigned to successors' expected skills, in that successor candidates are considered qualified to enter management positions if they possess the expected hard skills; however, they are expected to supplement these skills with a comprehensive range of soft skills. Sharma and Rao (2000) research found the highest-ranked attributes are integrity, commitment to the family firm, decision-making ability, self-confidence and employees' respect. Hard skills refer to jobrelated technical skills, cognitive abilities and formal, learnable expertise (Bereiter \& Scardamalia, 2006; Laker \& Powell, 2011; Moss \& Tilly, 2001)-skills that are objectively measurable and demonstrable (e.g., certificates). In contrast, intangible and difficult-to-measure soft skills reflect "skills, abilities, and traits that pertain to personality, attitude, and behavior" (Moss \& Tilly, 2001), such as motivation, communication, team spirit and self-confidence. The emphasis on morality is closely related to the Chinese culture, which attaches great importance to credit for customers and personal ethics in business activities, and is conducive to the business performance of enterprises. In addition, to develop leadership abilities, it is necessary for the successors not only to be trained before joining the company, but also to continue that training throughout their career within the family firms (Fiegener, Brown, Prince, \& File, 1994). The research results show that when selecting and deciding successor candidates, the three indicators of morality; leadership; work performance are the most important.

Table 2 GRA of Characteristics of Successors to Small and Medium-sized Family Businesses

\begin{tabular}{llll}
\hline Ranking & Characteristics & $\begin{array}{l}\text { Grey } \\
\text { Coefficient }\end{array}$ & Relational Key Characteristics \\
\hline 1 & Morality & 0.90 & V \\
\hline 2 & Leadership & 0.86 & V \\
\hline 3 & Work Performance & 0.76 & V \\
\hline 4 & Capabilities Other than Expertise & 0.69 & \\
\hline 5 & Seniority & 0.58 & \\
\hline 6 & External Conditions & 0.58 & \\
\hline
\end{tabular}

Small and medium-sized family businesses have the right to determine successors. According to Table 3, the selection of successors was mainly based on the opinions of the bosses or appointed chairmen, followed by the board of directors. As Taiwan is a country dominated by small and medium-sized enterprises, it is usually the chairmen or bosses that have substantial rights to the organizations. Woodfield and Husted (2017) stated that, generally, only 30\% fam-ily businesses in Asia can be successfully handed over to the second generation for operation, and only $10 \%$ of such businesses can be successfully handed over to the third generation. Bennedsen et al. (2015) state that the decision quality of family firm successors is an essential factor that will influence family growth and survival. How family firm successors develop a successful succession plan to enhance firm value is a key management concern for family firms pursuing longevity. Therefore, the selection of successors was mostly based on the opinions of the chairmen or bosses. 
INTERNATIONAL JOURNAL OF ACADEMIC RESEARCH IN BUSINESS AND SOCIAL SCIENCES Vol. 10, No. 7, July, 2020, E-ISSN: 2222-6990 @ 2020 HRMARS

Table 3 Main Positions Determining Successors to Small and Medium-sized Family Businesses

\begin{tabular}{lll}
\hline $\begin{array}{l}\text { Main Position Determining Selection of } \\
\text { Successor }\end{array}$ & Frequency & Ranking \\
\hline Boss & 142 & 1 \\
\hline Chairman & 142 & 1 \\
\hline Board of Directors & 111 & 2 \\
\hline Boss's Family & 86 & 3 \\
\hline Company Management & 58 & 4 \\
\hline Boss Couple & 46 & 5 \\
\hline
\end{tabular}

Based on the frequency distribution table, the study compared the expected effect between second generation successors to small and medium-sized family businesses and professional managers, as shown in Table 4. According to Table 4, about half (50.9\%) of the companies surveyed had plans of implementing or planning successors, and about $55.8 \%$ of the companies surveyed did not have actual succession planning or systems, which was consistent with the study of Calareso (2013). Although Taiwanese small and medium-sized family businesses faced the succession issue, more than half of them did not have actual succession planning. According to the comparison of the expected effect, more than half $(61.2 . \% \sim 72.4 \%)$ of the respondents believed that the companies should be managed by professional managers for the smoother succession and more trust from employees and that there would be substantial contribution to the corporate system, finances, and relationship with suppliers. This result was consistent with that of Boeker and Goodstein (1993), who believed that large organizations preferred internal successors. Since the study targeted small and medium-sized enterprises, the selection of professional managers as successors has a positive effect on the organizational change. Wilson (2014) also pointed out that family businesses engaged professional managers to assist in the business operations through the trust fund system in hopes of enhancing the overall business performance and avoiding professional managers from misappropriating public funds.

The results of this study are consistent with Ahrens, Landmann, and Woywode (2015), Villalonga and Amit (2006), Karaevli (2007) asuccession event in a family has positive significant impact on the business promotion performance of the business. The succession of a CEO by a non-family member has a greater business promotion performance, as compared with that of a family member. Besides the research found are different from others, research found that a family owned business is more willing to select an insider as the new CEO when the incumbent CEO is a family member (Luan, Chen, Huang \& Wang, 2018). Therefore, when a family business chooses a successor, it will decide the target based on its corporate culture second generation successors or professional managers. 
INTERNATIONAL JOURNAL OF ACADEMIC RESEARCH IN BUSINESS AND SOCIAL SCIENCES Vol. 10, No. 7, July, 2020, E-ISSN: 2222-6990 @ 2020 HRMARS

Table 4 Comparison between Second generation Successors to Small and Medium-sized Family Businesses and Professional Managers

Unit: \%

\begin{tabular}{|l|l|l|}
\hline Question & Yes & No \\
\hline Are there any succession plans and systems? & $44.2 \%$ & $55.8 \%$ \\
\hline Are there plans and systems relating to the planned successors? & $50.9 \%$ & $49.1 \%$ \\
\hline & $\begin{array}{l}\text { Second } \\
\text { generation } \\
\text { Successors }\end{array}$ & $\begin{array}{l}\text { Professional } \\
\text { Managers }\end{array}$ \\
\hline $\begin{array}{l}\text { Should the company be managed by the second generation } \\
\text { successor or a professional manager? }\end{array}$ & $35 \%$ & $65 \%$ \\
\hline Which successor will deliver the smoother succession? & $38.8 \%$ & $61.2 \%$ \\
\hline Which successor will receive obedience from employees more? & $29.2 \%$ & $70.8 \%$ \\
\hline $\begin{array}{l}\text { Which successor will have a greater impact on the company's } \\
\text { performance? }\end{array}$ & $31.8 \%$ & $68.2 \%$ \\
\hline Which successor will have a greater impact on suppliers? & $35.4 \%$ & $64.6 \%$ \\
\hline $\begin{array}{l}\text { Which successor will improve the continuity of the corporate } \\
\text { system? }\end{array}$ & $27.6 \%$ & $72.4 \%$ \\
\hline $\begin{array}{l}\text { Which successor will have a greater impact on the company's } \\
\text { finances? }\end{array}$ & $38.3 \%$ & $61.7 \%$ \\
\hline
\end{tabular}

Source: The study.

\section{Conclusion and Suggestion}

Our findings make several contributions to the family business field. We conclude that the process of selecting family successors is systematic and well considered. According to the results of the study, the key characteristics of successors to small and medium-sized family businesses were morality, leadership, and work performance, which reflected the main training methods for successors (job rotation and reserve cadre); that is, successors were trained with practical experience and capabilities through work and selected based on work performance and morality; in addition, the selection of successors was mainly determined by the bosses or chairmen of family businesses. Most of the small and medium-sized family businesses in Taiwan selected professional managers as successors because professional managers delivered the smoother succession, received obedience from employees more, made substantial contribution to the continuity and development of the corporate system, and improved the business performance and finances. This shows that the professionalism and communication skills of professional managers are more recognized by the employees compared with those of second generation successors. Taiwan is an Asian country dominated by small and medium-sized enterprises. In addition to the traditional business model, small and medium-sized family businesses have inherited Western business concepts and kept close contact with Western companies, thereby forming a special business model.

Succession is an important issue for companies. Especially family business succession is more complicated, and the problem of corporate succession has been plagued by Taiwanese companies. This study uses grey relational analysis to screen the key characteristics and training methods of successors, which is important for family succession related research Help, especially for Asian 
companies when choosing successors. The study targeted small and medium-sized enterprises in Taiwan, where small and medium-sized enterprises account for about $70 \%$ of the total enterprises. Currently, the average age of CEOs is about 62 years old, showing that the small and medium-sized enterprises are in urgent need of finding and cultivating successors. The training methods for successors, characteristics of successors, and comparison between second generation successors and professional managers provided in the study can serve as a reference to the owners of small and medium-sized enterprises in Taiwan; in addition, small and medium-sized enterprises in Taiwan are facing the problem of whether the second generation family members are willing to succeed. It is recommended that family members participate in corporate work and receive professional training and business management training to enhance their identification of the industry and family business. Many studies pointed out that the business performance of family businesses where professional managers succeeded could compete with that of family businesses where family members succeeded. It is recommended that family businesses cultivate the family members and non-family professional managers when selecting successors and institutionalize the management and internal control mechanisms that may protect the sound finances and continuity of family businesses where professional managers are selected as successors in the future.

\section{References}

Ahlers, O., Hack, A., \& Kellermanns, F. W. (2014). Stepping into the buyers' shoes: Looking at the value of family firms through the eyes of private equity investors. Journal of Family Business Strategy, 5(4), 384-396.

Ahrens, J. P., Landmann, A., \& Woywode, M. (2015). Gender preferences in the CEO successions of family firms: Family characteristics and human capital of the successor. Journal of Family Business Strategy, 6(2), 86-103.

Almeida, H., \& Wolfenzon, D. (2006). A theory of pyramidal ownership and family business groups. The Journal of Finance, 61(6), 2637-2680.

Anderson, R. C., \& Reeb, D. M. (2003). Founding-Family Ownership and Firm Performance: Evidence from the S\&P 500. Journal of Finance, 58(3), 1301-1328.

Anderson, R. C., \& Reeb, D. M. (2004). Board composition: Balancing family influence in S\&P 500 firms. Administrative science quarterly, 49(2), 209-237.

Bamford, C. E., Bruton, G. D., \& Hinson, Y. L., (2006). Founder/Chief excutive officer exit: A social capital perspective of new ventures. Journal of Small Business Management, 44(2), 207-220.

Barach, J. A., Gantisky, J., Carson, J. A., \& Doochin, B. A. (1988). Entry of the next generation:

Strategic challenge for family business. Journal of Small Business Management, 26(2), 49-56.

Bennedsen, M., Joseph, P. H. F., Minh, J., \& Yin-Hun, Y. (2015). The family business map: Framework, selective survey, and evidence from Chinese listed firms. Journal of Corporate Finance, 33, 212-226.

Bereiter, C., \& Scardamalia, M. (2006). Education for the knowledge age: Designcentered models of teaching and instruction. In P. A. Alexander \& P. H. Winne (Eds.), Handbook of educational psychology (2nd ed., pp. 695-714).

Bloom, N., \& Van Reenen, J. (2007). Measuring and explaining management practices across firms and countries. The Quarterly Journal of Economics, 122(4), 1351-1408.

Boeker, W., \& Goodstein, J. (1993). Performance and successor choice: The moderating effects of governance and ownership. Academy of Management Journal, 36(1), 172-186. 
INTERNATIONAL JOURNAL OF ACADEMIC RESEARCH IN BUSINESS AND SOCIAL SCIENCES

Vol. 10, No. 7, July, 2020, E-ISSN: 2222-6990 @ 2020 HRMARS

Brockhaus, R. H. (2004). Family business succession: Suggestions for future research. Family Business Review, 17(2), 165-177.

Cabrera-Suarez, K., De Saa-Perez, P., \& Garcia-Almeida, D. (2001). The succession process from a resource- and knowledge-based view of the family firm. Family Business Review, 14, 37-48.

Calareso, J. P. (2013). Succession planning: The key to ensuring leadership. Planning in Higher Education, 41(3), 27-33.

Cano-Rubio, M., Fuentes-Lombardo, G., \& Vallejo-Martos, M. C. (2017). Influence of the lack of a standard definition of "family business" on research into their international strategies. European Research on Management and Business Economics, 23(3), 132-146.

Cater, J. J., III, \& Kidwell, R. E. (2014). Function, governance, and trust in successor leadership groups in family firms. Journal of Family Business Strategy, 5(3), 217-228.

Chung, C. N., \& Luo, X. R. (2013). Leadership succession and firm performance in anemerging economy: Successor origin, relational embeddedness, and legitimacy. Strategic Management Journal, 34(3), 338-357.

Churchill, N. C., \& Hatten, K. J. (1987). Non-market-based transfers of wealth and power: A research framework for family business. American Journal of Small Business, 11(3), 51-64.

Claessens, S., Djankov, S., \& Lang, L. H. P. (2000). The separation of ownership and control in East Asian corporations. Journal of Financial Economics, 58(1-2) 81-112.

Dalton, D. R., \& Kesner, I. F. (1983). Inside/outside succession and organizational Size: The pragmatics of executive replacement. Academy of Management Journal, 26, 736-742.

Drucker, P. F. (1986). Management: Tasks, responsibilities, practices. truman talley Books.

Eddleston, K. A., \& Kellermanns, F. W. (2007). Destructive and productive family relationships: A stewardship theory perspective. Journal of Business Venturing, 22(5), 545-565.

Farrington, S. M., Venter, E., \& Sharp, G. D. (2014). Extrinsic rewards in family businesses: Perspectives of nonfamily employees. South African Journal of Business Management, 45(3), 67-79.

Fiegener, M., Brown, B., Prince, R., \& File, K. (1994). A comparison of successor development in family and non-family businesses. Family Business Review, 7(4), 313-329.

Friedman, S. D. (1986). Succession system in large corporations: Characteristics and correlates of performance. Human Resource Management, 25, 191-213.

Friedman, S. D., \& Saul, K. (1991). A Leader's wake: Organization member reactions to CEO succession. Journal of Management, 17(3), 619-642.

Fukuyama, F. (1995). Trust: The social virtues and the creation of prosperity. New York, NY: Free Press.

Garman, R., \& Tyler, I. (2004). What kind of CEO will your hospital need next? Model for succession planning. Trustee, 57(9), 38-40.

Goel, S., \& Roessl, D. (2015). Cooperatives and cooperative behavior in the context of family businesses. Journal of Co-operative Organization and Management, 3(2), 49-51.

Greer, C., \& Virick, M. (2008). Diverse succession planning: Lessons from the industry leaders. Human Resource Management, 47(2), 351-367.

Groves, K. S. (2007). Integrating leadership development and succession planning best practices. Journal of management development, 26(3), 239-260. 
INTERNATIONAL JOURNAL OF ACADEMIC RESEARCH IN BUSINESS AND SOCIAL SCIENCES

Vol. 10, No. 7, July, 2020, E-ISSN: 2222-6990 @ 2020 HRMARS

Hamilton, E., Cruz, A. D., \& Jack, S. (2017). Re-framing the status of narrative in family business research: Towards an understanding of families in business. Journal of Family Business Strategy, 8(1), 3-12.

Handler, W. C. (1994). Succession in family business: A review of the research. Family Business Review, 7, 133-157.

Hauck, J., Suess-Reyes, J., Beck, S., Prugl, R., \& Frank, H. (2016). Measuring socioemotional wealth in family-owned and-managed firms: A validation and short form of the FIBER scale. Journal of Family Business Strategy, 7(3), 133-148.

Hsu, D. K., Wiklund, J., Anderson, S. E., \& Coffey, B. S. (2016). Entrepreneurial exit intentions and the business-family interface. Journal of Business Venturing, 31(6), 613-627.

Kansikas, J., \& Kuhmozen, T. (2008). Family business succession: Evolutionary Economics Approach. Journal of Enterprising Culture, 16(3), 279-289.

Karaevli, A. (2007). Performance consequences of new CEO “Outsiderness" moderating effects of pre- and post-succession contexts. Strategic Management Journal, 28, 681-706.

Konopaski, M., Jack, S., \& Hamilton, E. (2015). How family business members learn about continuity. Academy of Management Learning \& Education, 14(3), 347-364.

Kram, K. E., \& Isabella, L. A. (1985). Mentoring alternatives: The role of peer relationships in career development. Academy of management Journal, 28(1), 110-132.

La Porta, R., Lopez-de-Silanes, F., \& Shleifer, A. (1999). Corporate ownership around the world. The Journal of Finance, 54(2), 471-517.

Laker, D. R., \& Powell, J. L. (2011). The differences between hard and soft skills and their relative impact on training transfer. Human Resource Development Quarterly, 22(1), 111-122.

Lansberg, I. S. (1988). The succession conspiracy family. Business Review, 1(2), 118-143.

Lansberg, I., \& Gersick, K. (2015). Educating family business owners: The fundamental intervention. Academy of Management Learning \& Education, 14(3), 400-413.

Levy, M. (2009). Control in pyramidal structures. Corporate Governance: An International Review, 17(1), 77-89.

Longenecker, J. G., \& Schoen, J. E. (1978). Management succession in family business. Journal of Small Business Management, 16(3), 1-6.

Luan, C. J., Chen, Y. Y., Huang, H. Y., \& Wang, K. S. (2018). CEO succession decision in family businesses-A corporate governance perspective. Asia Pacific Management Review, 23, 130136.

Maloni, M. J., Hiatt, M. S., \& Astrachan, J. H. (2017). Supply management and family business: A review and call for research. Journal of Purchasing and Supply Management, 23(2), 123-136.

Mark, H. D., \& Tom, M. C. (2013). Family wealth management. Singapore: John Wiley \& Sons.

Miller, D. (1993). Some organizational consequences of CEO succession. Academy of Management Journal, 36, 644-659.

Morck, R., \& Yeung, B. (2003). Agency problems in large family business groups. Entrepreneurship Theory and Practices, 27(4), 367-382.

Morck, R., Wolfenzon, D., \& Yeung, B. (2005). Corporate governance, economic entrenchment, and growth. Journal of economic literature, 43(3), 655-720.

Moss, P., \& Tilly, C. (2001). Stories employers tell: Race, skill, and hiring in America. New York, NY: Sage.

Mussolino, D., \& Calabro`, A. (2014). Paternalistic leadership in family firms: Types and implications 
INTERNATIONAL JOURNAL OF ACADEMIC RESEARCH IN BUSINESS AND SOCIAL SCIENCES

Vol. 10, No. 7, July, 2020, E-ISSN: 2222-6990 @ 2020 HRMARS

for intergenerational succession? Journal of Family Business Strategy, 5(2), 197-210.

Pandey, S., \& Sharma, D. (2014). Succession planning practices and challenges: study of Indian.

Procedia Economics and Finance, 11, 152-165.

Pe'rez-Gonza'lez, F. (2006). Inherited control and firm performance. American Economic Review, XCVI, 1559-1588.

Salvato, C., Sharma, P., \& Wright, M. (2015). From the guest editors: Learning patterns and approaches to family business education around the world-issues, insights, and research agenda. Academy of Management Learning \& Education 14(3), 307-320.

Schlepphorst, S., \& Moog, P. (2014). Left in the dark: Family successors' requirement profiles in the family business succession process. Journal of Family Business Strategy, 5, 358-371.

Scholes, L., \& Wilson, N. (2014). The importance of family firm trusts in family firm governance. Entrepreneurship Theory and Practice, 38(6), 1285-1293.

Seymour, K. C. (1993). Intergenerational relationships in the family firm: The effect on leadership succession. Family Business Review, 6, 263-281.

Sharma, P. (2004). An overview of the field of family business studies: Current status and directions for the future. Family Business Review, 16, 1-36.

Sharma, P., \& Rao, A. S. (2000). Successor attributes in Indian and Canadian family firms: A comparative study. Family Business Review, 13(4), 313-330.

Sorenson, R. L., \& Milbrandt, J. M. (2015). A family affair-Teaching families versus individuals: Insights gained from 24 years of family business education. Academy of Management Learning \& Education, 14(3), 366-384.

Steier, L. P., \& Miller, D. (2010). Pre-and post-succession governance philosophies in entrepreneurial family firms. Journal of Family Business Strategy, 1(3), 145-154.

The Economist. (2018). Taiwanese bosses are the Chinese-speaking world's oldest.

Tirdasari, N. L., \& Dhewanto, W. (2012). Family business succession in Indonesia: A study of hospitality industry. Procedia Social and Behavioral Sciences, 57, 69-74.

Villalonga, B., \& Amit, R. (2010). Family control of firms and industries. Financial Management, 39, 863-904.

Wang, Y. Z., Lo, F. Y., \& Weng, S. M. (2019). Family businesses successors knowledge and willingness on sustainable innovation: The moderating role of leader's approval. Journal of innovation \& knowledge, 4, 188-195.

Waruiru, W. E., \& Kagiri, A. W. (2013). Effects of succession planning strategy on the performance of international non-governmental organizations in Kenya. International Journal of Science and Research, 4(5), 3147-3155.

Weidenbaum, M., \& Hughes, S. (1996). The bamboo networks. New York, NY: Martin Kessler Books.

Woodfield, P., \& Husted, K. (2017). Intergenerational knowledge sharing in family firms: Case-based evidence from the New Zealand wine industry. Journal of Family Business Strategy, 8(1), 5769.

Xu, N., Yuan, Q., Jiang, X., \& Chan, K. C. (2015). Founder's political connections, second generation involvement, and family firm performance: Evidence from China. Journal of Corporate Finance, 33(Special issue C), 243-259.

Yeh, Y. H. (2019). Corporate governance and family succession: New evidence from Taiwan. PacificBasin Finance Journal, 57, 1-16.

Young, M. N., Peng, M. W., Ahlstrom, D., Bruton, G. D., \& Jiang, Y. (2008). Corporate governance in 
INTERNATIONAL JOURNAL OF ACADEMIC RESEARCH IN BUSINESS AND SOCIAL SCIENCES Vol. 10, No. 7, July, 2020, E-ISSN: 2222-6990 @ 2020 HRMARS

emerging economies: A review for the principal-principal perspective. Journal of Management Studies, 45(1), 196-220. 